\title{
Ruptured Aneurysm on a Persistent Primitive Hypoglossal Artery Associated with Unilateral Moyamoya Disease
}

\author{
Tomohiro Araki, M.D., Ph.D., and Kenji Kanamaru, M.D., Ph.D.
}

Summary: A persistent primitive hypoglossal artery (PPHA) is a rare anomalous remnant that can be associated with vascular anomalies such as cerebral aneurysm, moyamoya disease, or arteriovenous malformation. An aneurysm developing in a PPHA associated with unilateral moyamoya disease has not previously been reported. We describe the case of a patient in whom an aneurysm ruptured on a PPHA associated with unilateral moyamoya disease. A 42-year-old man who developed a sudden severe headache followed by unconsciousness was diagnosed with a subarachnoid hemorrhage (SAH) at our hospital. Three-dimensional computed tomography (3D-CT) angiography and catheter cerebral angiography revealed an aneurysm on a left PPHA and left middle cerebral artery occlusion with basal moyamoya vessels. The aneurysm was successfully clipped. The postoperative course was uneventful, and the patient returned to work without neurological deficits three weeks after the surgery.

\author{
Key words: \\ - primitive persistent \\ hypoglossal artery \\ - unilateral moyamoya \\ disease \\ - cerebral aneurysm \\ - subarachnoid hemorrhage
}

Surg Cereb Stroke

(Jpn) 44: 477-481, 2016

\section{Introduction}

A persistent primitive hypoglossal artery (PPHA) is a rare anomalous remnant that can be associated with vascular anomalies such as cerebral aneurysm, moyamoya disease, or arteriovenous malformation, as well as with risk for intracranial hemorrhage. An aneurysm developing in a PPHA associated with unilateral moyamoya disease has not previously been reported (Table 1). We describe the case of a patient in whom an aneurysm ruptured on a PPHA associated with unilateral moyamoya disease.

\section{Case report}

A 42-year-old man who presented to our hospital with a sudden severe headache followed by unconsciousness was diagnosed with subarachnoid hemorrhage (SAH) grade IV, according to the World Federation of Neurosurgical Surgeons Committee (WFNS) SAH scoring system.

He had no history of hypertension. His body mass index was $24.9 \mathrm{~kg} / \mathrm{m}^{2}$. Upon admission, his blood pressure was 131/80 $\mathrm{mmHg}$, and his heart rate was 72 beats/min with a regular sinus rhythm. Levels of serum blood glucose, hemoglobin A1c, and low-density lipoprotein cholesterol were 146 $\mathrm{mg} / \mathrm{dl}, 5.5 \%$, and $149 \mathrm{mg} / \mathrm{dl}$, respectively. Thyroid function was normal. Levels of protein $\mathrm{C}$ and $\mathrm{S}$ were within normal limits, and the results of tests for antithrombin, anticardiolipin antibodies, antinuclear antibodies, anti-DNA antibodies, and lupus anticoagulant were negative.

Plain computed tomography (CT) revealed moderate $\mathrm{SAH}$ in the basal cistern and thick SAH in the posterior cranial fossa (Fig. 1).

Three-dimensional (3D) CT angiography revealed an aneurysm on the left PPHA. The aneurysmal neck was localized at the junction between the PPHA and the vertebral artery $6 \mathrm{~mm}$ from the hypoglossal canal (Fig. 2A). Left carotid angiography showed a PPHA originating from the left internal carotid artery, running postero-superiorly at the level of the $\mathrm{C} 2$ vertebra, entering the posterior cranial fossa through the hypoglossal canal, and forming an anastomosis with the basilar artery. A left middle cerebral artery occlusion with basal moyamoya vessels was also shown (Fig. 2B, C). A left posterior communicating artery was not evident. Right ver-

Department of Neurosurgery, Suzuka Kaisei Hospital (Received February 11, 2016) (Accepted June 30, 2016) [Mailing address: Tomohiro ARAKI, M.D., Ph.D., Department of Neurosurgery, Suzuka Kaisei Hospital, 112-1 Kou, Suzuka, Mie 513-8505, Japan] 
Table 1 Summary of patients with cerebral aneurysms associated with both a persistent primitive hypoglossal artery (PPHA) and moyamoya disease

\begin{tabular}{ccccccc}
\hline Case No. & Author (year) & Age & Sex & PPHA laterality & Onset & Site of aneurysm \\
\hline $1^{*}$ & Kurose et al. $(1989)^{5)}$ & 44 & F & Left & Infarction & Basilar tip \\
$2^{*}$ & Komiyama et al. (1999) $)^{6)}$ & 54 & F & Left & Subarachnoid hemorrhage & Basilar tip \\
3 & Present report & 42 & M & Left & Subarachnoid hemorrhage & PPHA \\
\hline
\end{tabular}

*These reports refer to the same patient, PPHA: persistent primitive hypoglossal artery

$\mathbf{A} \mid \mathbf{B}$
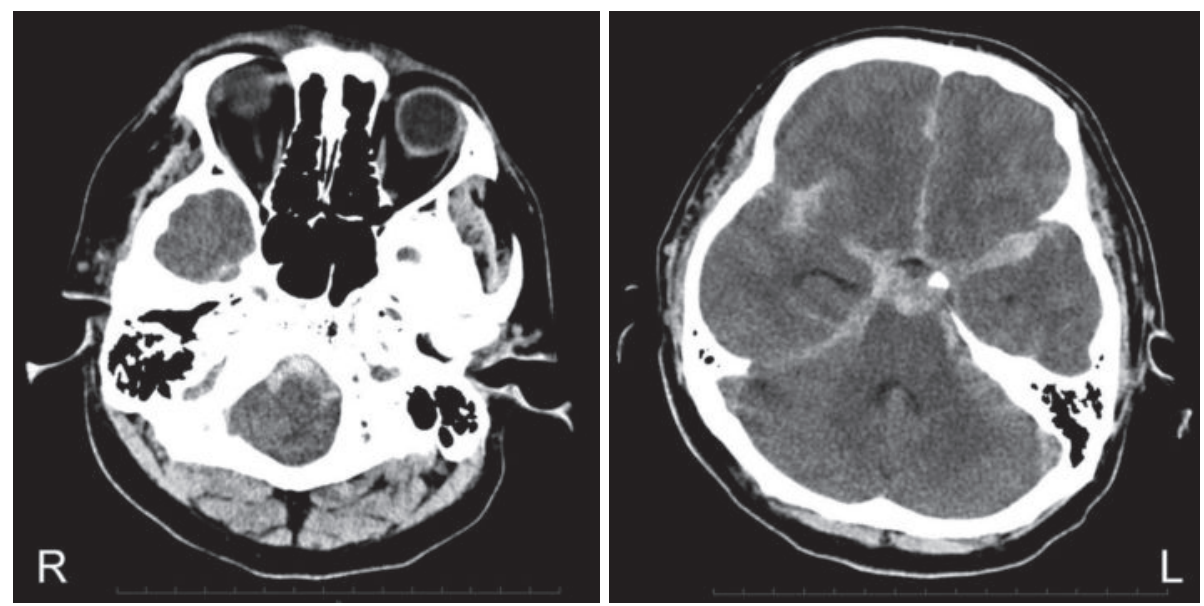

Fig. 1 Plain cranial computed tomography findings upon admission.

Thick hematoma is evident at the anterior edge of the foramen magnum $(\mathbf{A})$ and subarachnoid hemorrhage (B).

\section{\begin{tabular}{l|l|l} 
& A \\
\hline B & C & D
\end{tabular}}

Fig. 2 Pre-operative three-dimensional computed tomography findings (A).

Image shows hypoglossal canal, persistent primitive hypoglossal artery, aneurysm (arrow), posterior inferior cerebellar artery (arrowhead) hypoplastic contralateral vertebral artery, and optimal view for neck clipping.

Left carotid and right vertebral angiography findings (B). Left carotid angiogram shows aneurysm located on persistent primitive hypoglossal artery (B arrow) and middle cerebral artery occluded with basal moyamoya vessels (unilateral moyamoya disease; C arrow). Right vertebral angiogram shows hypoplastic vertebral artery (D).


478 脳卒中の外科 44: 2016 



Fig. 3 Intraoperative photography (A)

A $\mid \mathbf{B} \quad$ Space is sufficient to apply aneurysm clip.

Post-operative three-dimensional computed tomography findings (B).

Aneurysm has been obliterated.


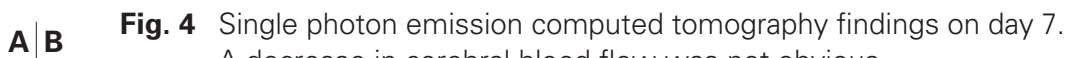
A decrease in cerebral blood flow was not obvious.

tebral angiography revealed both a hypoplastic right vertebral artery and posterior communicating artery (Fig. 2D). Thus, SAH due to a ruptured aneurysm was considered. Presurgical planning was based on 3D-CT angiography findings, and surgical intervention proceeded on the day when SAH occurred.

Sub-occipital craniectomy and decompression of the posterior rim of the foramen magnum and the posterior arch of the atlas proceeded with the patient in the park-bench position. Decompressing the foramen magnum and posterior arch of the atlas provided sufficient space for temporary clipping of the PPHA and complete clipping of the aneurysm neck (Fig. 2, 3).
Post-operative management comprised meticulous normovolemic and normotensive control. A decrease in cerebral blood flow on single photon emission computed tomography (SPECT) images was not obvious on day 7 (Fig. 4).

The postoperative course was uneventful, and the patient returned to work without neurological deficits three weeks after the surgery.

\section{Discussion}

The established developmental vascular anomalies include carotid-basilar anastomoses and primitive trigeminal, optic, hypoglossal, and proatlantic intersegmental arteries. The second most frequent type of persistent embryonic ca- 
rotid-basilar anastomoses after a primitive trigeminal artery is PPHA, with an occurrence rate of $0.02-0.26 \%$ of cerebral angiographic findings ${ }^{3) 10}$. A PPHA must arise from the cervical part of the internal carotid artery above the level of C3 and enter the posterior fossa via the hypoglossal canal. The basilar artery only fills beyond the point at which the hypoglossal artery enters. A posterior communicating artery on the same side is either absent or hypoplastic ${ }^{8)}$. A PPHA can be associated with vascular anomalies such as cerebral aneurysms or moyamoya disease, as well as with a risk of intracranial hemorrhage. Aneurysms of a primitive trigeminal artery occur relatively often, but very rarely on a PPHA itself in the general population ${ }^{1)-3 \text { ) }}$.

Moyamoya disease and unilateral moyamoya disease have been associated with persistent primitive arteries ${ }^{6)}$. The criteria for unilateral moyamoya disease is a unilateral steno-occlusive state of the internal carotid and/or anterior cerebral and middle cerebral arteries without atherosclerotic changes, and the development of moyamoya vessels on the same side. Furthermore, the contralateral intracranial vessels are either normal or lack the vascular changes typical of moyamoya disease. A steno-occlusive lesion associated systemic diseases are the exclusion criteria for both moyamoya disease and unilateral moyamoya disease ${ }^{9)}$. Komiyama et al. described a higher incidence of an association between moyamoya disease or unilateral moyamoya disease and persistent primitive arteries ${ }^{6}$. However, the presence of PPHA associated with moyamoya disease or unilateral moyamoya disease is very rare in the general population. Steno-occlusive changes in the internal carotid artery of moyamoya disease reduce blood flow in an area of anterior circulation, and develop collateral vessels of the posterior circulation. The dominant arterial supply in the posterior circulation can be the PPHA, which should be under hemodynamic stress; thus, disturbance of spontaneous closure occurs. Such combinations of vascular anomalies have previously been reported $^{4)}$.

The relationship between a PPHA and an aneurysm can be explained as the persistence of immature endothelial cells in the intima of the primitive artery and congenitally impaired apoptosis ${ }^{7}$. Both congenital structural defects in a vessel wall and hemodynamic stress on the PPHA might account for the tendency of these lesions to rupture in the subarachnoid space.

Diagnosis and treatment of such conditions are critical because a PPHA might be the only dominant posterior circu- lation supply and could be supplied from the posterior to the anterior circulation. The ultimate goal of treatment is to exclude the aneurysmal sac without compromising the PPHA. Endovascular treatment is acceptable, especially for aneurysms in the posterior circulation. Aneurysms are less amenable to coiling when the neck is wide rather than narrow. The aneurysm was localized at a site $6 \mathrm{~mm}$ out of the hypoglossal canal in our patient, indicating a potential location for temporary clipping during surgery. However, we selected direct treatment because the ratio of the aneurysmal neck to the dome was 1.3. An aneurysm of a PPHA associated with unilateral moyamoya disease should be directly treated to allow the option of vascular reconstruction. Careful examination of the anatomical relationship with the skull base and surrounding vascular structures is important for planning neurosurgical procedures and directly clipping an aneurysm. We found that 3D-CT angiography was helpful to diagnose the aneurysmal SAH and to understand complex and anomalous anatomical structures. Clipping the aneurysm was straightforward for this patient, and follow-up 3D-CT angiography revealed its obliteration.

\section{Conclusion}

This is the first description of a patient with a ruptured aneurysm on a PPHA associated with unilateral moyamoya disease. Under these conditions, a PPHA might act as the sole dominant posterior fossa arterial supply.

Careful examination of the anatomical relationship with the skull base and surrounding vascular structures is important for planning neurosurgical procedures and directly clipping aneurysms. 3D-CT angiography was helpful for locating the aneurysm and visualizing complex or anomalous anatomical structures.

\section{References}

1) Al-Memar A, Trush D: Unilateral hypoglossal nerve palsy due to aneurysm of the stump of persistent hypoglossal artery. L Neurol Neurosurg Psychiatry 64: 405, 1998

2) Duffill J, Lang DA, Dwyer GN: Subarachnoid haemorrhage in a child from an aneurysm of a persistent primitive hypoglossal artery. Br J Neurosurgery 10: 607-610, 1996

3) Kanai H, Nagai H, Wakabayashi $\mathrm{S}$, et al: A large aneurysm of the persistent primitive hypoglossal artery. Neurosurgery 30: 794797, 1992

4) Katayama W, Enomoto T, Yanaka K, et al: Moyamoya disease associated with persistent primitive hypoglossal artery. Pediatr Neurosurg 35: 262-265, 2001

5) Kurose K, Kishi H, Sadatoh T: Moyamoya disease with persistent hypoglossal artery. Neural Med Chir (Tokyo) 29: 528-532, 
1989 [Article in Japanese]

6) Komiyama M, Nakajima H, Nishikawa M, et al: High incidence of persistent primitive arteries in moyamoya quasi-moyamoya disease. Neurol Med Chir (Tokyo) 39: 416-422, 1999

7) Krings T, Lasjaunias PL, Geibprasert S, et al: The aneurismal wall. The key to a subclassification of intracranial arterial aneurysm vasculopathies? Interv Neuroradiol 14 (Suppl 1): 3947,2008

8) Lasjaunias P, Brugge ter KG, Berenstein A: Surgical Neuroangiography. Vol 1, Chapt 3. Berlin, Heidelberg, Springer-Verlag,
1987

9) Takagi Y: Research on intractable disease of the Ministry of Health, Labour and Welfare, Japan: Recommendations for the management of moyamoya disease. A statement from research committee in spontaneous occlusion of the circle of Willis (moyamoya disease). Surg Cereb Stroke 37: 321-337, 2009 [Article in Japanese]

10) Vlychou M, Georganas M, Spanomichos G, et al: Angiographic findings and clinical implications of persistent primitive hypoglossal artery. BMC Med Imaging 3: 2, 2003

Unilateral moyamoya disease に合併した persistent primitive hypoglossal artery aneurym の 1 例

\section{荒木 朋浩，金丸 憲司}

鈴鹿回生病院 脳神経外科

persistent primitive hypoglossal artery(PPHA) 自体に発生した 動脈瘤は, 比較的まれである. moyamoya disease や unilateral moyamoya disease に persistent primitive artery の合併は比較的 高頻度と報告されているが, PPHA 動脈瘤の合併例の報告はなく まれである.われわれは, 42 歳男性, 意識障害で発症した unilateral moyamoya disease に合併したPPHA 動脈瘤破裂によるくも 膜下出血の 1 例を経験したので, 文献的考察を加えて報告する. 治療は, 術前 CT angiography (CTA) にて頭蓋内で十分に proxi- mal control が可能と判断できたので, park bench position で hypoglossal canal が十分に確認できるように foramen magnum 開 放, occipital condyle 直近までの骨削除, 第 1 澒椎の laminectomy を行い neck clipping を行った，経過は順調で，神経学的異常を残 さず退院した. unilateral moyamoya disease を合併する PPHA 動 脈瘤では確実な再破裂の予防と脳循環動態の維持が重要である. 手術計画については3D CTAが有用であった. 